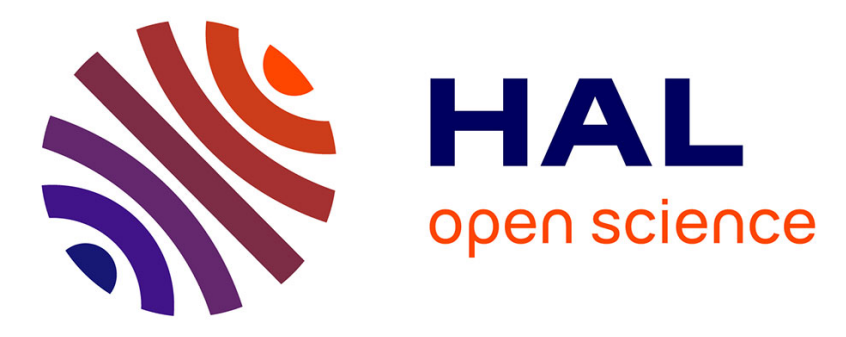

\title{
Instrumental semantic map in Western Iranian languages
}

Masoud Mohammadirad, Mohammad Rasekh-Mahand

\section{To cite this version:}

Masoud Mohammadirad, Mohammad Rasekh-Mahand. Instrumental semantic map in Western Iranian languages. STUF - Language Typology and Universals , 2017, 10.1515/stuf-2017-0025 . halshs02864521

\section{HAL Id: halshs-02864521 https://shs.hal.science/halshs-02864521}

Submitted on 11 Jun 2020

HAL is a multi-disciplinary open access archive for the deposit and dissemination of scientific research documents, whether they are published or not. The documents may come from teaching and research institutions in France or abroad, or from public or private research centers.
L'archive ouverte pluridisciplinaire HAL, est destinée au dépôt et à la diffusion de documents scientifiques de niveau recherche, publiés ou non, émanant des établissements d'enseignement et de recherche français ou étrangers, des laboratoires publics ou privés. 


\title{
Masoud Mohammadirad* and Mohammad Rasekh-Mahand Instrumental semantic map in Western Iranian languages
}

https://doi.org/10.1515/stuf-2017-0025

\begin{abstract}
This paper aims to study instrumental related functions in some Western Iranian languages. The data were collected from descriptive grammars, and interviews in some cases. Narrog's instrumental semantic map is the basis for analyzing polysemy patterns in these languages. The data show that two main polysemy patterns are attested: (1) Instrumental and companion functions are coded alike. (2) They are coded differently. These two patterns are distributed areally. Furthermore, some languages are shifting/have shifted between these two types mainly as a result of contact-induced matters. In languages in which two or more functions are not directly connected, one marker generally has both instrumental and dative functions.
\end{abstract}

Keywords: semantic map, connectivity, instrumental marker, polysemy patterns, Western Iranian languages

\section{Introduction}

Semantic maps are tools which represent cross-linguistic regularities in the mapping of meaning on form (Narrog and Ito 2007: 273). They are tools for the representation of the polyfunctionality of words and more generally constructions (Auwera 2013: 154). Multifunctionality is prominent with grammatical morphemes (affixal categories and function words) and these morphemes have more abstract and general meanings and thus are more apt to be used in multiple ways than content words (Haspelmath 2003: 211). Croft (2003: 133) claims that a semantic map is a way for representing language universals and language-specific grammatical knowledge. In his words, the semantic map model does not assume that categories are universal across languages, it only

*Corresponding author: Masoud Mohammadirad, Université Sorbonne Nouvelle Paris 3, UMR 7528 - Mondes Iranien et Indien - CNRS, 27, Rue Paul Bert, 94200 Ivry-sur-Seine, Paris, France, E-mail: rad.masud@gmail.com.

Mohammad Rasekh-Mahand, Faculty of Literature and Humanities, Bu-Ali Sina University, Hamedan, Iran, E-mail: mrasekhmahand@yahoo.com. 
assumes that conceptual space and certain relations between categories in conceptual space are universal (Croft 2003: 196). Semantic maps have been proposed for diverse aspects of linguistics structure (Cysouw et al. 2010), including tense/aspect (Anderson 1982; Janda 2007; Croft and Poole 2008), modality (Anderson 1986; Awera and Plungian 1998), voice (Kemmer 1993; Croft 2001), pronouns (Haspelmath 1997a; Cysouw 2007), case marking (Haspelmath 2003; Narrog and Ito 2007; Rice and Kabata 2007), clause linkage (Malchukov 2004), Spatial and temporal domain (Haspelmath 1997b; Levinson et al. 2003), intransitive predication (Stassen 1997), and secondary predication (Auwera and Malchukov 2005).

The present paper investigates functions of instrumental marker in Western Iranian languages. Narrog's instrumental semantic map (Narrog 2010: 243), which is a revised form of his shared work with Ito (Narrog and Ito 2007), is the basis for analyzing instrumental functions in these languages. Figure 1 shows the proposed map by Narrog:

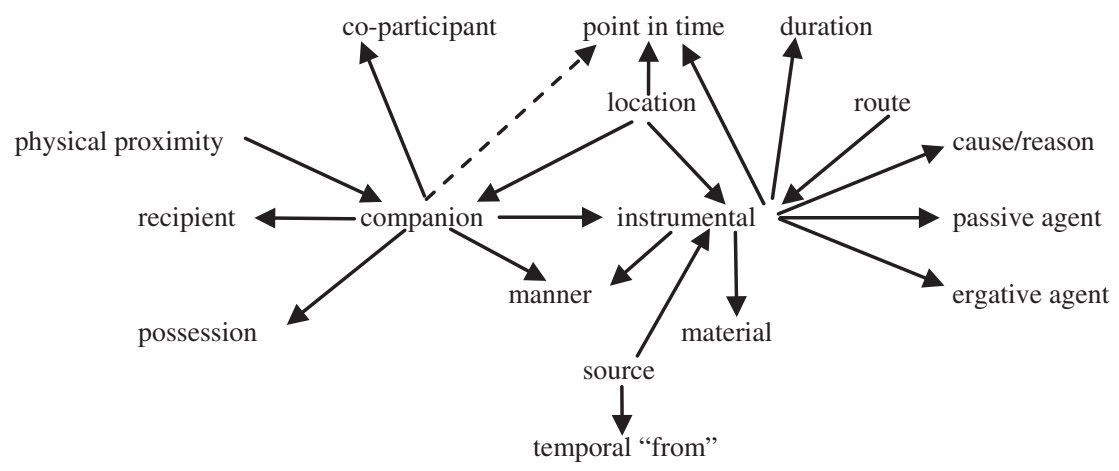

Figure 1: Narrog’s (2010) Instrumental Semantic Map.

This map is based on the study of 200 languages. The drawing of map is based on two assumptions: (1) Each function should occur at least across 10 morphemes in the studied languages, and then the relation between meanings is calculated so that if the occurrence of one meaning depends on another meaning by more than $90 \%$, the existence of connections between these two meaning is hypothesized. (2) On singular co-occurrence of one meaning with a specific other meaning; if the morpheme $M$ has only the meanings $A$ and $\mathrm{B}$, and this situation occurs in at least three different languages, there is a direct connection between these two meanings (Narrog and Ito 2007: 281). 
The map is a diachronic one, and the arrows show directions of change between meanings. In this map, instrumental and companion are the core functions; their polysemy is the largest across language phyla (Narrog and Ito 2007: 287), and nearly all other functions are evolved from these two functions. An important point about semantic maps is that they may contain implicational universals, for instance, if a marker encodes instrumental and recipient, it should also encode companion, which is between these two functions on the map. Another point about markers is that they should cover connected regions on the map. This point has been named connectivity (Croft 2003), proximity (Haspelmath 2003), and adjacency (Auwera and Plungian 1998) in the literature. There have been some attempts to deal with polysemy in the instrumentalcomitative domain. One can mention Luraghi (2001), Haspelmath (2003), and Yamaguchi (2004). Narrog and Ito (2007) argued against these maps and based on huge empirical data falsified a number of specific connections hypothesized in them.

According to Stolz et al. (2013), languages are classified into three groups in terms of encoding instrumentals and comitatives (companion in our term): (1) identity group, in which instrumental and companion are encoded alike, (2) differentiation group, in which instrumental and companion are encoded differently, and (3) mixed group, in which both identity and differentiation of instrumental and companion exist. They conclude that apart from Europe, every continent favors differentiation of instrumental and companion.

The question we try to answer is whether or not Narrog's proposed map can account for instrumental related functions in Western Iranian languages? And whether or not are there polysemy patterns exclusive to these languages? Also, we aim to show areal distributions of polysemy patterns in these languages. The topic is interesting since Iranian languages have not been elaborated on in Narrog's map, and their polysemy behaviors can shed light on further research for similar polysemy patterns across languages.

\section{Instrumental related functions in Western Iranian languages}

In this section, we discuss instrumental related functions in Western Iranian languages. The Iranian languages constitute the western group of the larger Indo-Iranian family which represents a major eastern branch of the IndoEuropean languages (Windfuhr 2009: 1). They are classified into western and 
eastern sub-branches based on primarily phonological features, but also morphological ones.

According to Lehman and Shin (2005: 33-34, cited in Narrog 2009) seven strategies for the coding of concomitant functions, including instrumental, exist among which studied Iranian languages use case marking and adpositional marking.

\subsection{Western Iranian languages}

The under-investigated new Western Iranian languages include New Persian, Bakhtiari, Gilaki, Mazandarani, Taleshi, Balochi (western), Koroshi, Tati (Chali dialect), Northern Kurdish, Central Kurdish, Southern Kurdish, Gorani, Hawrami, and Tat (Juhuri variety). Among these, New Persian, Bakhtiari, and Tat are categorized as south-western, and the rest as north-western sub-branch of Western Iranian languages (Windfuhr 2009: 12-13). For each language, we provide functions of the instrumental marker, then we discuss the attested polysemy patterns and the conformity of the resultant maps to Narrog's map. The data from descriptive grammars are quoted with small changes in the transcription used by authors. To avoid ambiguity in the interpretation of functions, we provided examples of prototypical instances of these functions on Narrog's map. For instance, prototypical 'recipient' is the one encoding 'recipient phrase' in 'give constructions' (Newman 1996: 82).

\subsubsection{New Persian}

In New Persian, preposition $b \bar{a}$ ( $a b \bar{a} g$ in Middle Persian) marks instrumental related functions, including instrument (1a), companion (1b), co-participant (1c), manner (1d), and cause (1e):

(1) a. dar rā bā kelid bāz kard-am

door OBJ INS key open do.PST-1SG

'I opened the door with a key'

[personal interview]

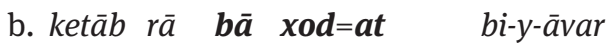

book OBJ INS REFL=2SG.PC IMP-EP-bring.2SG.IMP

'Bring the book with yourself'

[personal interview] 
c. man $\boldsymbol{b} \overline{\boldsymbol{a}}$ xāhar=am davā kard-am

1SG INS sister=1SG.PC fight do.PST-1SG

'I fought with my sister'

[personal interview]

d. Minā bā ajaleh àmad

PN INS haste come.PST.3SG

'Mina came hastily'

e. elāhi javūn marg be-š-i

[personal interview]

God young death IMP-become-2SG daughter INS DEM

šohar-e pāpati ke peydā kard-i

husband-EZ ${ }^{1}$ wretched COMP find do.PST-2SG

'Daughter! May you die soon because of finding such a wretched husband!'

[Najafi 1999: 107]

Figure 2 shows the map for $b \bar{a}$ :

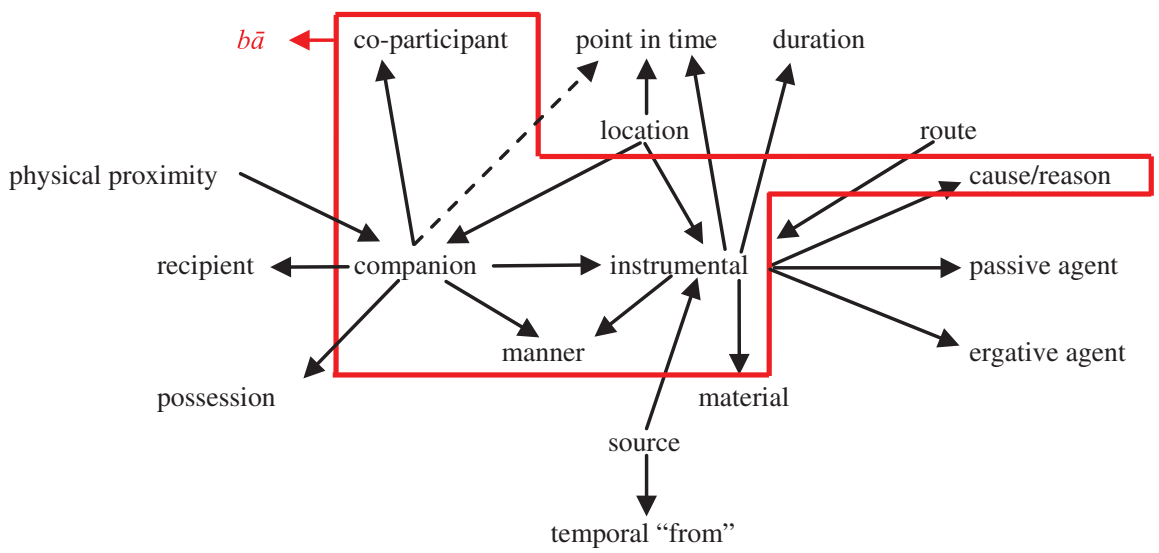

Figure 2: Functions of $b \bar{a}$ in New Persian.

In Bakhtiari, another south-western Iranian language, as in New Persian, one marker encodes polysemy in the instrumental-comitative domain. Here, $v \bar{a} / v \bar{a} b \bar{a}$ encodes functions of instrument (2a), companion (2b), co-participant (2c), and manner (2d):

1 Ezafe, a feature of certain Western Iranian languages, refers to an element which links the head noun to its modifiers and to the possessor NP (Samvelian 2007: 605). 
(2) a. $\boldsymbol{v} \overline{\boldsymbol{a}} \boldsymbol{d i n}=\boldsymbol{e s}$ āsiyav-ne roft

INS tail=3SG.PC mill-OBJ sweep.PST.3SG

'He swept the mill with its tail'

[Anonby and Asadi 2014: 118]

b. haf=tā kize por ze telā vo norğe-ne vā

seven=CLF jug full from gold and silver-OBJ INS

$\boldsymbol{x} \boldsymbol{O}=\boldsymbol{s}$ bord be qasr.

self=3SG.PC take.PST.3SG to palace

'He took with himself the seven jugs which were full of gold and silver to the palace.'

[Anonby and Asadi 2014: 113]

c. ya ru vābā zeyne=s men=e bā̆ e-torokest

one day INS wife=3SG.PC in=EZ garden IPFV-walk.PST.3SG

'One day when he was walking in the garden with his wife'

[Anonby and Asadi 2014: 114]

d. $b e=s$ go hamočo be-mahn-e o vā

to=3SG.PC say.PST.3SG right there SBJV-stay.PRS-3SG and INS

āsāyešt zendei bo-kon-e

comfort life SBJV-do.PRS-3SG

'(He) asked him to stay right there and have a comfortable life'

[Anonby and Asadi 2014: 116]

In both New Persian and Bakhtiari connectivity is observed and instrumental and companion functions are encoded alike.

\subsubsection{Gilaki}

The Gilaki language is spread along the southern shore of the Caspian Sea in one of the northern provinces of Iran known as Gilan (Rastorgueva et al. 2012: 1). In Gilaki, two adpositions encode instrumental related functions: -amra marks instrument (3a), companion (3b), and co-participant (3c). The other preposition, bå, code instrument (3d), companion (3e), co-participant (3f), and manner (3g):

(3) a. kulangว-amra zuyål kan-idi pick.GEN-INS coal dig out.PRS-2/3PL

'They are digging out coal with a pick' [Rastorgueva et al. 2012: 170]

b. tan-om ti-amra har jo̊ bi-g-i b-á-y-əm.

can-1SG 2SG.GEN-INS every place SBJV-say-2SG SBJV-go-EP-1SG

'I can come with you wherever you say.' [Rastorgueva et al. 2012: 243] 
c. ašanə-amra vasti mubarazə kud-ən.

3PL.GEN.PROX-INS must fighting do.PST-INF

'We must fight them. (lit. It is necessary to fight them)'

[Rastorgueva et al. 2012: 337]

d. šåyəd ušan-am bå $\boldsymbol{u}$ nigåh-an xéyli čiz-án-a perhaps 3PL-too INS DEM glance-PL much thing-PL-ACC/DAT hamdigár-a bə-fahm-ane-idi.

each other-ACC/DAT SBJV-understand.PRS-CAUS-2/3PL

'Perhaps they too, explained many things to each other with these glances.'

[Rastorgueva et al. 2012: 285]

e. dåmåd-ə mår bå čən=ta pir-zənək-an

bridegroom-GEN mother INS several=CLF old-woman-PL

a-idi asb-ə sar-ə gir-idi

come.PRS-2/3PL horse-GEN head-ACC/DAT take.PRS-2/3PL

arus- $a$ bar-idi bålåxåne

bride-ACC/DAT carry.PRS-2/3PL attic

'The bridegroom's mother comes together with several old women, hold the horse's head, and take the bride into the upper room'

[Rastorgueva et al. 2012: 397]

f. arus-ə per=u mår=əm bå čən=ta

bride-GEN father=and mother=TOP INS several=CLF

pir-zənək-an=u rišsəfid-an-ə dihåt məšzul-ə taayi

old-woman-PL=and elder-PL-EZ village busy-EZ preparation

kud-ən durust kud-ən-ə šåm $=u \quad$ yəza $b$-id

do.PST-INF right do.PST-INF-EZ supper=and food be.PST-2/3PL

'The bride's parents and several old women and honorable old men from the village were busy with the preparation of supper'

[Rastorgueva et al. 2012: 393]

g. Ahmadǰan salam! bå a tund-i kóya

PN hello INS this fast-ADVLZ where

šuo-n dar-i

go.PST-INF have.AUX-2SG

'Hello, Ahmed! Where are you going so hurriedly?'

[Rastorgueva et al. 2012: 328]

The map for Gilaki is displayed in Figure 3 below. As seen on the map, these two adpositions are synonymous, but their synonymy is not absolute; $b a$ covers one function more than -amra. If they were completely synonymous, they would violate the principle of economy and iconicity in grammar (Croft 2003: 106). 


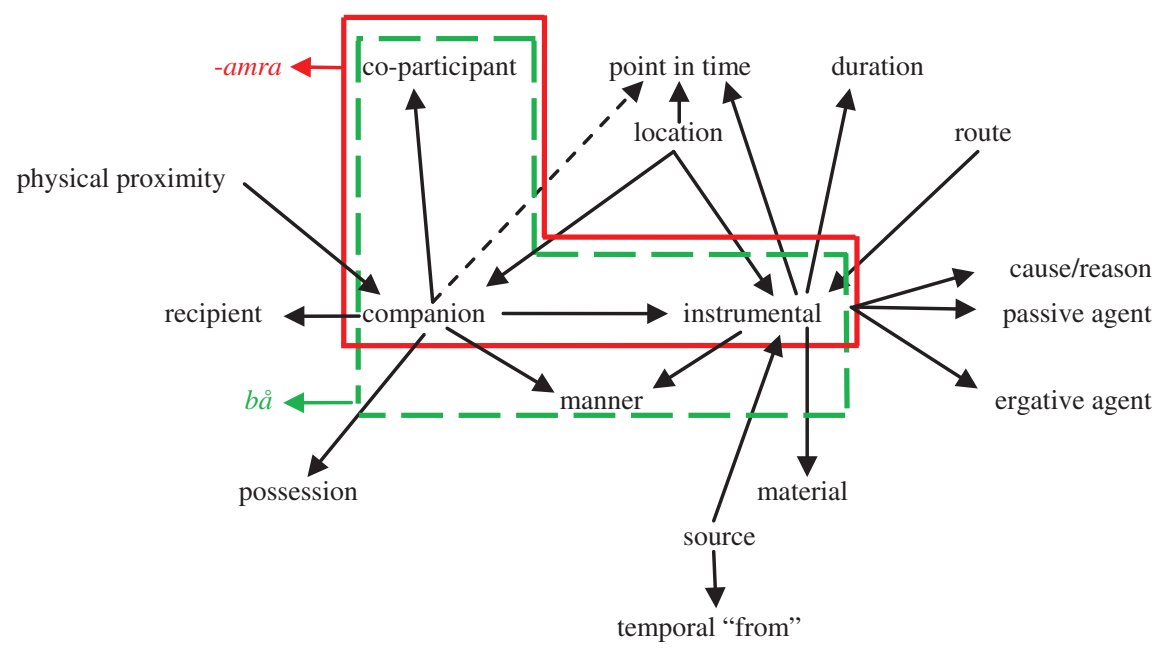

Figure 3: Functions of -amra and bå in Gilaki.

\subsubsection{Mazandarani}

Mazandarani belongs to the Caspian subgroup of north-western Iranian languages (Stilo 2016). In Mazandarani, the postposition $=j e$, or $=j a$, and $=j \bar{a}$ as its allomorphs, encode polysemy in the instrumental-comitative domain. -je encodes instrument (4a), companion (4b), co-participant (4c), source (4d), recipient (4e), and location (4f):

\section{(4) a. balu=je binj kźrd-emi}

hoe.GEN=INS ice-paddy sow.PST-1PL

'We sowed the rice-paddy with the hoe'

b. kin=je kār hākārd-i?

who.GEN=INS work do.PST-2SG

'With whom did you work?'

[Stilo 2016: 8]

c. $\boldsymbol{m} \boldsymbol{e}=\mathbf{j} \bar{a}$ davā ken-ne

1SG.GEN-INS fighting do.PRS-3SG

'He'll fight with me'

[Stilo 2016: 8]

d. $\boldsymbol{s} \boldsymbol{a} \boldsymbol{h} \mathbf{\boldsymbol { a }}=\mathbf{j a} \quad$ bemo

field.GEN-INS came.PST.3SG

'He came from the field'

[Stilo 2016: 8] 
e. in kāqez-re ven=je baresen

this paper-OBJ 3SG.GEN-INS send.IMP

'Send this letter to her'

[Stilo 2016: 8]

f. cārr-rā sar=je pul pidā hekārd-imi

intersection-INS money find do.PST-1PL

'We found money at the intersection'

[Stilo 2016: 8]

Boundaries of -je $(-j a,-j \bar{a})$ are shown in Figure 4.

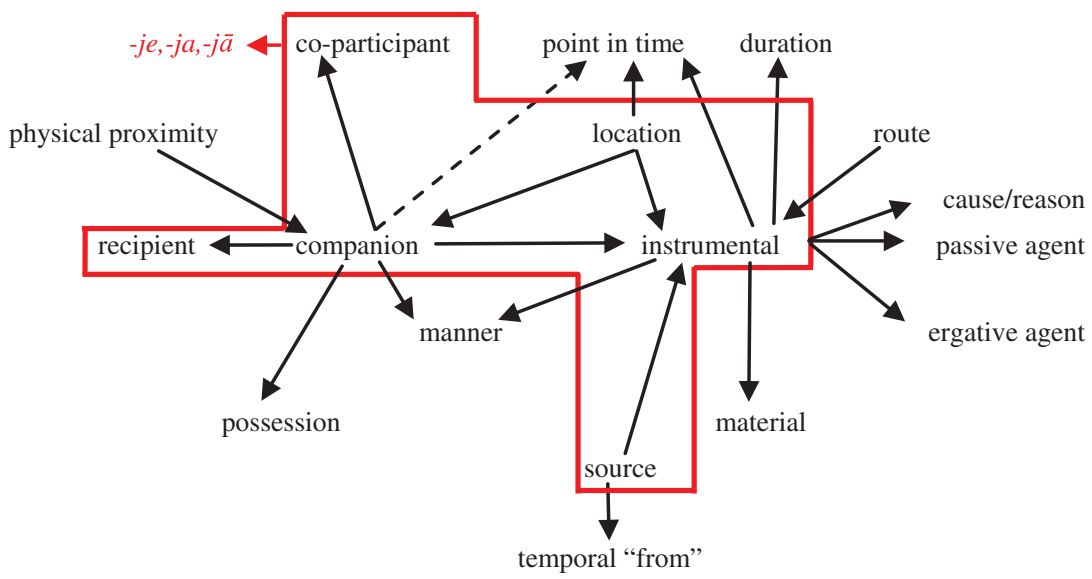

Figure 4: Functions of $-j e(-j a,-j \bar{a})$ in Mazanderani.

As the map shows, Instrumental polysemy observes connectivity in Mazanderani.

\subsubsection{Balochi}

The data belong to the variety of Balochi spoken in Mari region in Turkmenistan which belongs to the western branch of Balochi (Jahani and Korn 2009: 637). Here, the preposition gō encodes instrument (5a), companion (5b), co-participant $(5 \mathrm{c})$, and recipient $(5 \mathrm{~d})$ :

a. $\check{s} \bar{e} r-\bar{a} \quad$ gō yakk tīr-ēe kušt.

lion-OBJ INS one arrow-INDF kill.PST.3SG

'He killed a lion with one arrow.'

[Axenov 2006: 64] 
b. gō wat čunt swār u xizmatkār-āa burt.

INS REFL several rider and servant-OBJ take away.PST.SG

'He took with him several riders and servants.' [Axenov 2006: 136]

c. gō wat-ī mard-ā dar būt-an pa gardišt- $\bar{a}$

INS REFL-GEN husband-OBL PVB be.PST-1PL for walk-OBL

'I and my husband went out for a walk'

[Axenov 2006: 144]

d. nasrō gō mardum-ān iččì na-gušt

PN INS man-PL nothing NEG-Say.PST.3SG

'Nasro did not tell the people anything'

[Axenov 2006: 71]

Boundaries of gō in Balochi are shown in Figure 5.

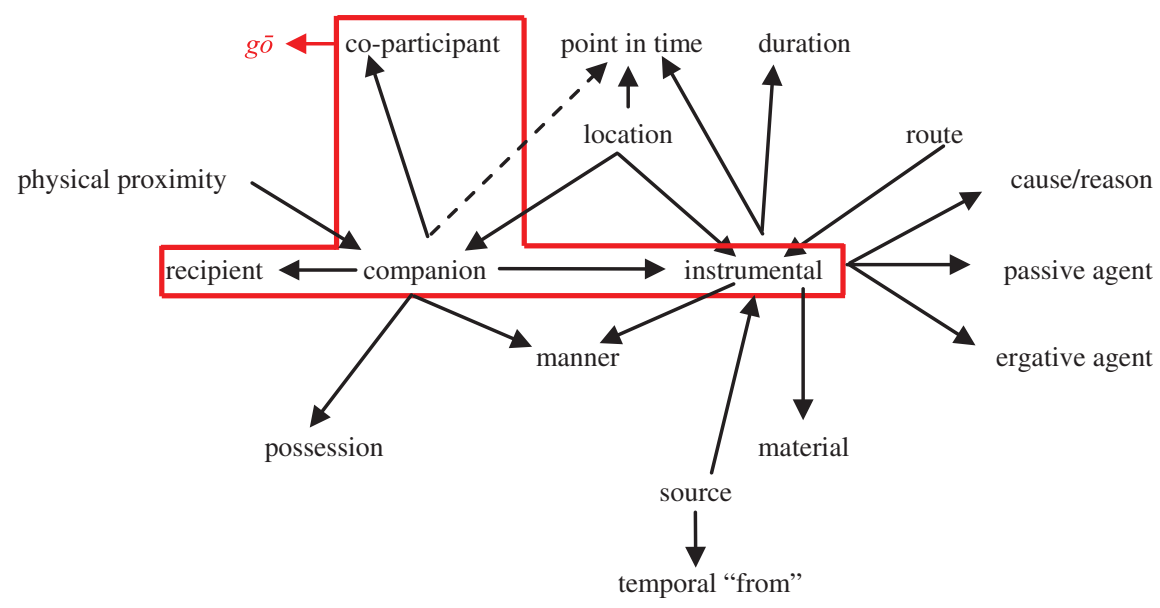

Figure 5: Functions of $g \bar{o}$ in Balochi.

The same preposition encodes instrumental-related functions in Koroshi, a language closely related to the southern varieties of Balochi. In Koroshi, gō encodes instrument (6a), companion (6b), and co-participant (6c):
a. $\boldsymbol{g} \overline{\boldsymbol{O}}$ sīb- $\overline{\boldsymbol{a}}$ be-jan-t
$m \bar{a}$ joğla-bār-ay sīnā

INS apple-OBL SBJV-hit.PRS-3SG in boy-PL-GEN chest.OBL

'She should hit [one of] those boys in the chest with the apple'

[Nourzaei et al. 2015: 29] 
b. man raxt $=$ o lebās $=$ om gō telā $=m$

PN.1SG clothes=and clothes=1SG INS gold=1SG.PC

$m e-d-\bar{a} n=t e$

IMP-give.PRS-1SG=2SG.PC

'I will give my clothes along with my gold to you'

[Nourzaei et al. 2015: 48]

c. godda go wad=et bokān=om bìy-ā-on

then INS REFL=2SG.PC want=1SG.PC SBJV-come.PRS-1SG

$\log -\bar{a}$

house-OBL

'Then I want to come home with you' [Nourzaei et al. 2015: 149]

In both Balochi and Koroshi, the common polysemy pattern is for instrumental and companion functions to be coded alike.

\subsubsection{Taleshi}

Taleshi is spoken along the southern part of the Caspian Sea's west coast (Paul 2011: 15). The Talesh region is commonly divided into three general dialect areas: Northern, Central, and Southern (Paul 2011: 18). Instrumental marker in Northern Taleshi is different from that of central and southern Taleshi, thus we describe them separately.

In Northern Taleshi, the postposition -anda marks instrument (7a), companion (7b), co-participant (7c) location (7d), point in time (7e), and manner (7f):

(7) a. $d u$ sa-ku sord-anda be-š- $a=b \partial$

tree head-LOC ladder-INS PST-go-PTCP=AUX.3SG

'He had gone up the tree by means of a ladder'

[Paul 2011: 162]

b. av fağat bâla-nda uma

3SG only child-INS came.PST.3SG

'He came with only the child'

[Paul 2011: 162]

c. bâl-ân yad=anda pecxa-na-n

child-PL RECP=INS fight-IPFV-3PL

'The children are fighting against one another'

[Paul 2011: 91]

d. mânə gužd-i ki` ̌̆âb-anda süt- $a=b$ o

SG.OBL meat-RCH REL pot-INS burnt-PTCP=AUG.3SG

hârd-am-e

eat.PST-1SG-TR

'I ate the meat that was burnt in the pot'

[Paul 2011: 192] 
e. cušt-a

lunch-LNK

$a-k$-im

AUG-do-IPFV.1PL

'At lunchtime, we used to prepare dugh using yoghurt'

f. koluk šuršur=anda vua-na-y

rain vigour=INS rain-IPFV-3SG

'It is raining heavily'

[Paul 2011: 238]

[Paul 2011: 180]

In central and southern Taleshi -na encodes instrument (8a), companion (8b), co-participant (8c), source (8d), manner (8e), and physical proximity (8f):
a. dâs-i-na
am-i
žan-ə, los-i-na
am-i
žan-ə

sickle-OBL-INS 3SG-OBL hit-3SG stick-OBL-INS 3SG-OBL hit-3SG

'He hits him with a sickle, he hits with him a stick' [Paul 2011: 162]

b. av fağat bâla-na uma

3SG only child-INS came.3SG

'He came with only the child'

c. a-e âm-in sava=šu ba-na jam $\hat{a}-k a r d=a$

[Paul 2011: 162]

3-PL came-3PL basket=3PL.PC 3SG.IO-INS collect PVB-make.be=TR

'They came (and) collected up the basket with him'

[Paul 2011: 163]

d. dâr-i boni-na daivar-u

tree-OBL under-INS passed-3SG.SBJV

'... to pass under the tree'

[Paul 2011: 163]

e. $a$ žen-i narm-i-na gaf $\check{z} a$

DEM woman-OBL soft-OBL-INS speech hit.TR

'That woman spoke gently'

\section{f. $n u=\check{s}=a \quad$ ducarxa $=$ na \\ put $=3$ SG.PC $=$ TR bicycle $=$ INS}

'He put it on the front of the bicycle'

[Paul 2011: 78]

[Paul 2011: 78]

Figure 6 illustrates boundaries of -na (solid lines) and -anda (dashed lines).

In all dialects of Taleshi, instrumental marker covers connected regions on the map, thus observes connectivity. 


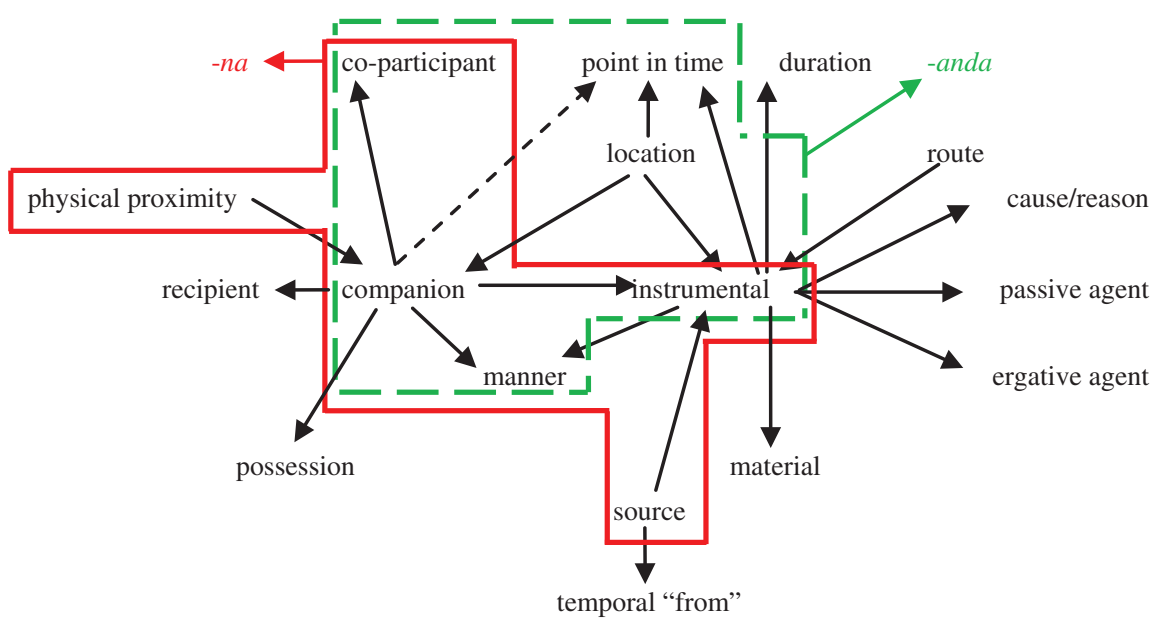

Figure 6: Boundaries of -na and -anda in Taleshi dialects.

\subsubsection{Tati}

Tati is a north-western Iranian language and is mainly spoken in some parts of Qazvin, Zanjan, and Azerbaijan provinces in Iran. The variety we describe its polysemy in the instrumental-comitative domain is Chali, a dialect of southern Tati (Yar-Shater 1969). In Chali, - $u$ and -endu both encode instrumental polysemy. - $u$ marks instrument (9a), companion (9b), source (9c), manner (9d), location (9e), and co-participant (9f). -endu encodes instrument (9 g), companion (9h), location (9i), and point in time (9j). In (14f), the postposition - $k u$ is used instead of $-u$; $-k u$ encodes companion for animate entities, and $-u$ for inanimate ones. $-\bar{o}$ and $-e n d a /$-ind $u$ are allomorphs of $-u$ and -endu respectively.

(9) a. darzan-ō bedut-em

needle-INS sew.PST-1SG

'I sewed with a needle'

b. bōmenda qörōn-u ša:m-u

come.PST.3PL Koran-INS candle-with

'They came with Koran and candle'

[Yar-Shater 1969: 120]

c. deraxt-u bečin

tree-INS pick.IMP

'Pick from the tree'

[Yar-Shater 1969: 119] 
d. $\boldsymbol{n a} \boldsymbol{z}-\boldsymbol{u} \quad$ pāmibi

grace-INS get up.2SG

'You were getting up with grace'

e. čeme ǰf-u

1SG.OBL pocket-INS

'In my pocket'

f. a mardak ke ̌̌oma-ku harf=eš mi-zand

[Yar-Shater 1969: 121]

DEM man COMP 2PL-INS talk=3SG.PC IPFV-do.PST

moallem-e

teacher-COP.3SG

'The man who was talking with you is a teacher'

[Dabir-Moghaddam 2013: 1095]

g. tir-enda menebe

beam-INS can't be done

'It can't be done with beam[s]'

h. bōmenda dāyro ye zerno-ndu

come.PST.3PL tambourine and hautboy-INS

'They came with tambourine and hautboy'

[Yar-Shater 1969: 123]

i. ešta tet-e vāzi-endu-ind

2SG.GEN girl-PL.DIR play-INS-COP.3PL

'Your girls are in the game'

[Yar-Shater 1969: 123]

. šava šeš sāat ë nim-indu

evening six clock EZ half-INS

'At 6:30 in the afternoon'

[Yar-Shater 1969: 123]

Figure (7) below shows boundaries of $-u$ and -endu in Chali.

$-u$ encodes more functions than -endu. In Tati, like Gilaki (Figure 4), two adpositions cover polysemy in the instrumental-comitative domain; they are synonymous but not completely.

\subsubsection{Kurmanji (Northern Kurdish)}

Kurdish is a cover term for the largest group of closely-related western Iranian dialects. There are three main subgroups of Kurdish: (1) Northern Kurdish is the most widely spoken variety of Kurdish, also known as Kurmanji. (2) Central Kurdish has two main subgroups, Sorani in northern Iraq up to the little Zab River, and Mukri in the adjacent Iranian province of Kordestan. (3) Southern Kurdish is found in the abutting areas of Iraq and Iran, from Khaneqin in Iraq 


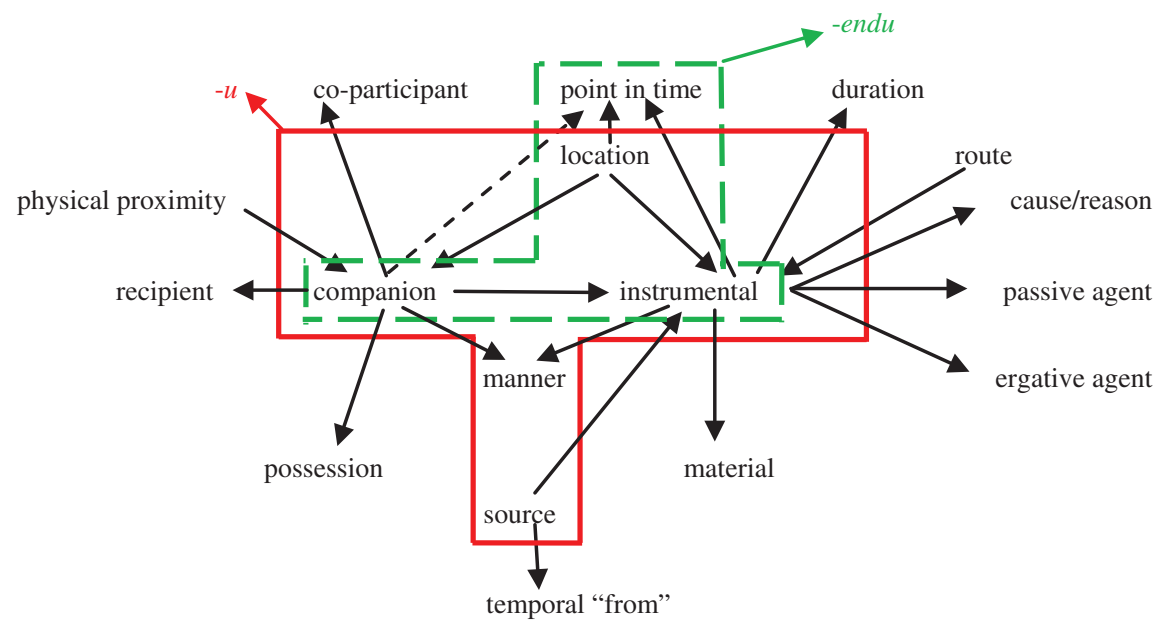

Figure 7: Boundaries of $-u$ and $-e n d u$ in Tati.

over to Kermanshah in Iran and down to the north of Al-Amra, Iraq, as well as in the Bijar region of Iran (McCarus 2009: 587).

In Kurmanji, the preposition bi encodes instrument (10a), manner (10b), point in time (10c), and location (10d), while the circumposition bi ...... re marks companion (10d), co-participant (10e), and possession (10f).

(10) a. gošt bi kēra xwe birī

meat INS knife REFL cut.PST

'He cut the meat with his own knife'

[Bedir Khan and Lescot 1970: 246]

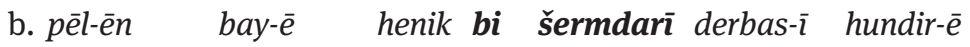
wave-IZ.PL wind-IZ.M cool INS modesty pass-IZ.M inside-IZ.M oda te di-bū-n

room.F 2SG.OBL IND-become.PST-3PL

'Waves of cool breeze were passing modestly into your room'

c. pištī rohelat-ēe bi du saet-an

[Thackston 2006a: 21]

after sunrise-OBL.F INS two hour-OBL.PL

'Two hours after sunrise'

[Bedir Khan and Lescot 1970: 246]

d. pere bi bērik-a xwe xist

money INS pocket-EZ.F REFL throw.PST

'He put the money in his pocket' [Bedir Khan and Lescot 1970: 246] 
e. me hamû tişt-ên xwe bi xwe re han̂े-n-e 1SG.OBL every thing-EZ.PL REFL ADP REFL ADP bring.PST-3PL-PRF 'I have brought my whole things with me'

[Thackston 2006a: 152]

f. ez di-xwaz-im bi sal-an bi te re 1SG.DIR IND-want.PRS-1SG for year-PL.OBL ADP 2SG.OBL ADP bi-jî̀-m SBJV-live.PRS-1SG

'I have wanted to live with you for years' g. lê $\hat{\imath} \hat{u}$ ne bi $\min$ re ye from today NEG ADP 1SG.OBL ADP COP 'It's not with me (in my possession) from today' [Thackston 2006a: 178] Boundaries of bi and bi ..... re are shown in Figure 8:

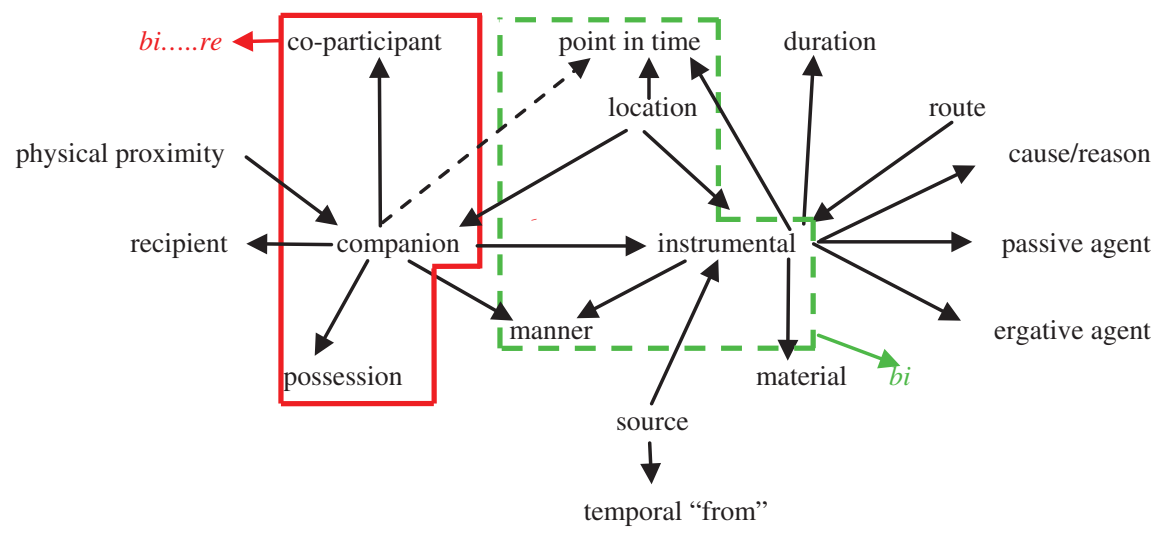

Figure 8: Boundaries of bi and bi.....re in Kurmanji.

In Kurmanji, unlike other languages we have seen so far, instrumental and comitative are not marked by the same marker, though connectivity is observed.

\subsubsection{Sorani (Central Kurdish)}

In Sorani, two prepositions encode instrumental-related functions, but they are not synonymous: ba encodes instrument (11a), passive agent (11b), recipient (11c), and manner (11d). For some functions like manner, instrumental, and 
recipient, $b a$ can be used together with postposition - $a w a$, thus forming a circumposition (11e). The other preposition, lagal, encodes companion (11h) and co-participant (11i). In (11b), pe is an absolute preposition variant of ba (McCarus 2009: 601).

(11) a. aw dirgā-ka=y ba klíl bāz kird

he door-DEF=3SG.PC INS key open do.PST

'He opened the door with a key' [Dabir-Moghaddam 2013: 604]

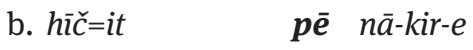

nothing=2SG.PC INS NEG-do-PASS

'Nothing can be done by you'

[Thackston 2006b: 167]

c. ama bít-em ba to

DEM SBJV-say-1SG INS 2SG

'(Let me) tell you that'

[Thackston 2006b: 23]

d. ba pala hāt

INS haste come.PST.3SG

'He came hastily'

[Thackston 2006b: 178]

e. kič-aká ba tūřaī-awa wit=ī

girl-DEF ADP angrily-ADP say.PST=3SG.PC

'The girl said angrily'

f. $b=y$-hen- $a \quad$ lagal $\boldsymbol{x o}=\boldsymbol{t}$

$\mathrm{IMP}=3 \mathrm{SG}$.PC-bring-IMP.2SG COM REFL=2SG.PC

'Bring that with yourself'

[Thackston 2006b: 39]

g. aw piyāw-a-y ka lagal to qis $a=y$

DEM man-DEF-EZ COMP COM 2SG talk=3SG.PC

a-kird māmostā-y-a

IPFV-do.PST teacher-EP-COP.3SG

'The man who was talking with you, is a teacher'

[Dabir-Moghaddam 2013: 605]

Figure 9 below shows boundaries of $b a$ and lagal in Central Kurdish.

What we see here is a violation of connectivity; instrumental and recipient are coded alike while companion is coded differently. Besides, $b a$ also encodes direction (11i) and experiencer (11h) which together with recipient are typical functions of dative markers (Haspelmath 2003).

(11) i. ‘̌u-n-a (=ba) bāzār

go.PST-3PL-to market

'They went to market'

[McCarus 2009: 605] 


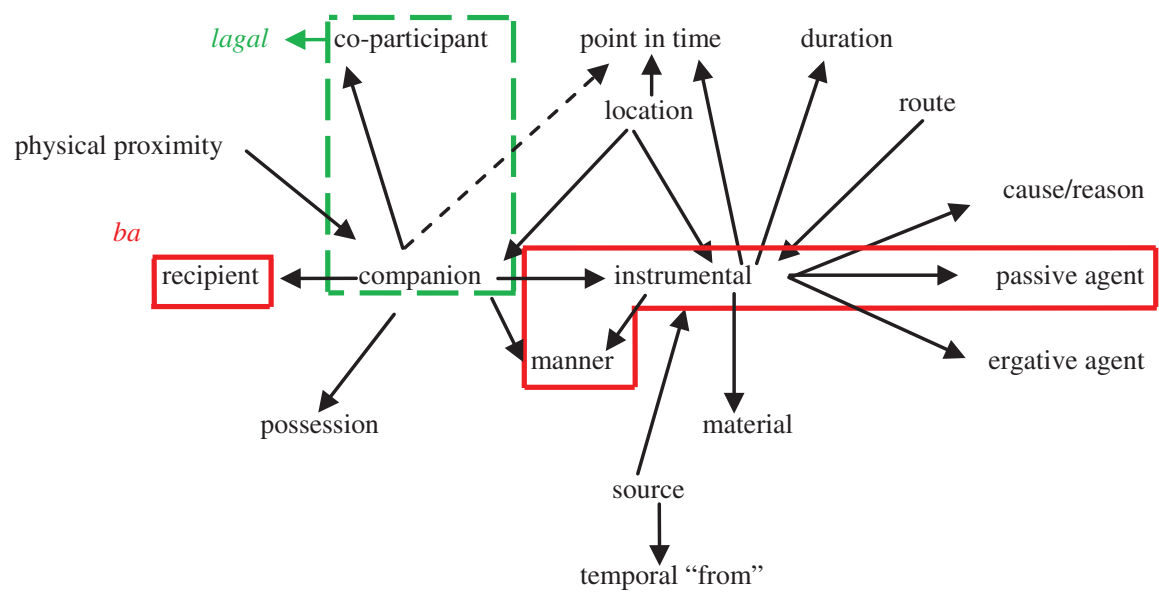

Figure 9: Boundaries of ba and lagal in Sorani.

h. $\boldsymbol{p} \bar{e}=\boldsymbol{m} \quad x o \check{s} \quad b \bar{u} \quad h \bar{a} t-\bar{l}$

to $=1$ SG.PC glad become.PST come.PST.2SG

'I'm glad you came (lit. It was nice to me that you came)'

[Thackston 2006b: 199]

In Sorani Kurdish, connectivity is not observed, and the instrumental marker also has dative functions. Actually, it is not clear whether the marker that encodes both dative and instrumental functions should be classified as an instrumental marker or as a dative one. Put differently, one marker realizes both instrumental and dative functions.

Here, lagal, takes companion and co-participant functions. The fact that it is a compound preposition consisting of $l a+g a l$ shows its recency as a preposition.

\subsubsection{Southern Kurdish}

For Southern Kurdish, we describe two dialects which behave differently in their polysemy correlations: (1) the Kalhori dialect, which is spoken in the west and south-west of Kermanshah province, in the west of Iran, and (2) Kermanshahi Kurdish, which is a variety of Kurdish spoken in the city of Kermanshah. 


\subsubsection{Kalhori Kurdish}

In Kalhori Kurdish, two prepositions encode instrumental related functions: $w a$, etymologically related to $b a$ in Sorani, encodes instrument (12a), manner (12b), source (12c), and recipient (12d). It also encodes direction (12e), which together with recipient are typical of dative functions. Wagard encodes companion (12f), and co-participant (12g):

a. me dar-aga wa kelil wāz kard-em

1SG door-DEF INS key open do.PST-1SG

'I opened the door with a key'

[Dabir-Moghaddam 2013: 649]

b. wa delaxwari hät-en

INS sadness come.PST-3PL

'They were sad when they came' [personal interview]

c. wa Sanandaj hät-em

INS PN come.PST-1SG

'I came from the way of Sanandj' [personal interview]

d. me ketāw-aga wa Maryam dā-m

1SG book-DEF INS PN give.PST-1SG

'I gave the book to Maryam' [Dabir-Moghaddam 2013: 649]

e. awāna la Terān wa Esfahān montaqel bü-n

3PL from PN INS PN move become.PST-3PL

'They were moved from Tehran to Esfahan'

[Dabir-Moghaddam 2013: 649]

\section{f. ketāw-aga wagard $\mathbf{x w}=\mathbf{a d} \quad b$-ār-a}

book-DEF COM REFL=2SG.PC IMP-bring-IMP.2SG

'Bring the book with yourself'

[personal interview]

g. piyā-ga ke dāšt wagard-e èwa sohbat kard mo?alem-a

man-DEF REL IPFV COM-EZ 2PL talk do.PST teacher-COP.3SG

'The man who was talking with you is a teacher'

[Dabir-Moghaddam 2013: 651]

Figure 10 below shows the map for Kalhori Kurdish.

Kalhori Kurdish is like Sorani Kurdish in its polysemy correlation; in these two varieties of Kurdish connectivity is not observed and one marker encodes instrumental and dative functions.

\subsubsection{Kermanshahi Kurdish}

Kermanshahi Kurdish is different from Kalhori Kurdish in its polysemy pattern in that only the preposition wagard encodes core instrumental functions: 


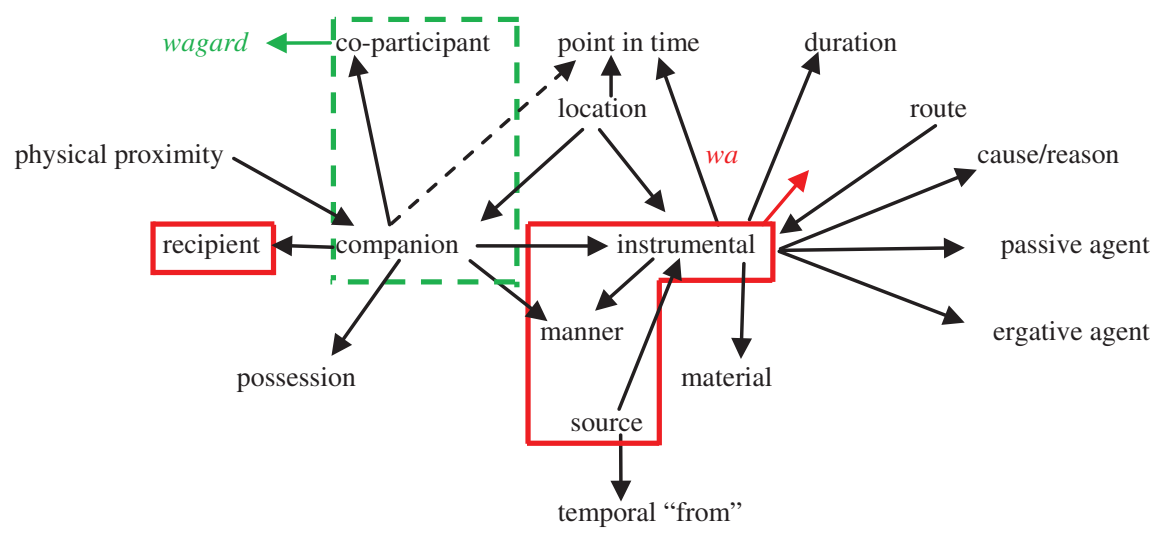

Figure 10: Boundaries of wa and wagard in Kalhori Kurdish.

(13) a. me wagard-e kelil dar-aga wā kard-em

1SG INS-EZ key door-DEF open do.PST-1SG

'I opened the door with a key' [Dabir-Moghaddam 2013: 650]

b. Nāser wagard-e minā hät

PN INS-EZ PN come.PST.3SG

'Naser came together with Mina'

c. Ali wagard-e rafiq-aga $=\mathbf{y}$ merāfa kord

PN INS-EZ friend-DEF=3SG.PC fight do.PST.3SG

'Ali fought with his friend'

[personal interview]

The map for Kermanshahi Kurdish is shown in Figure 11 below.

The situation we see for Kermanshahi Kurdish is interesting, since, unlike other Kurdish varieties (Sorani and Kalhori), connectivity is observed and instrumental and companion are coded alike, as is the case for new Persian (Figure 2). We assume it is due to the influence of Persian on the Kurdish variety spoken in Kermanshah that the functionality in instrumental domain observes connectivity. In Kermanshah, Kurdish and Persian are in intensive contact and it seems highly possible that the polysemy pattern we see for this variety of Kurdish is due to the influence of Persian.

\subsubsection{Gorani}

Gorani is spoken in western part of Kermanshah province in the west of Iran (Mahmudveysi et al. 2012: 1). While it is nowadays only spoken in a small 


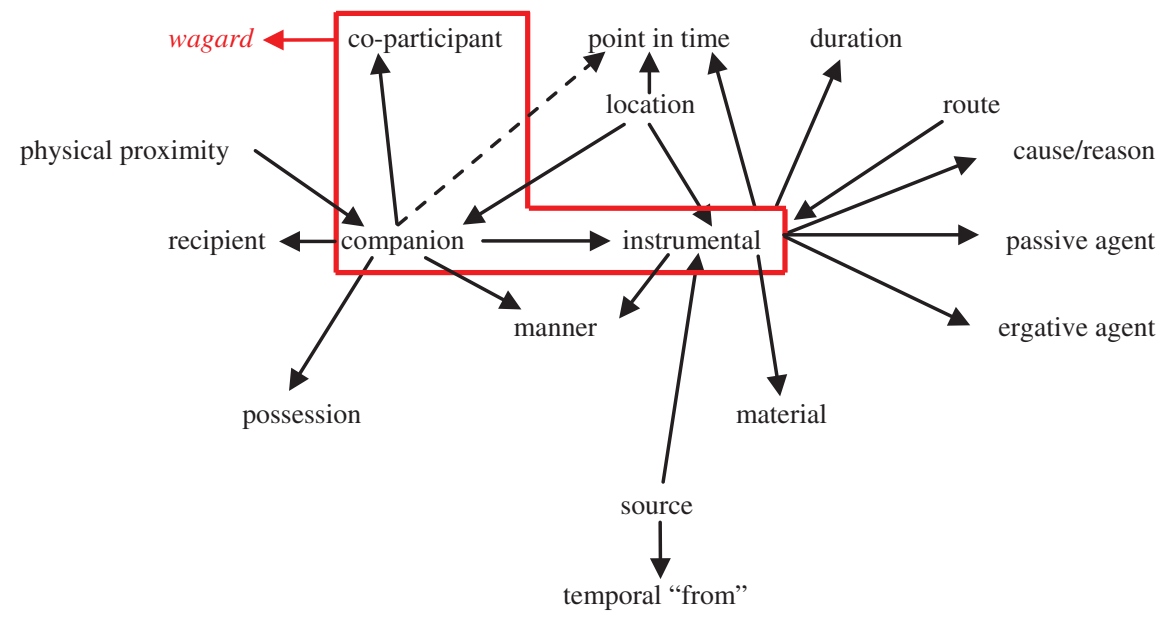

Figure 11: Boundaries of wagard in Kermanshahi Kurdish.

number of villages, it is assumed that it was formerly prevalent in a larger area. The variety of Gorani that is investigated here is Gawrajui (Mahmoudveysi et al. 2012). In Gorani, two prepositions encode instrumental related functions: wa marks instrument (14a), location (14b), manner (14c), point in time and companion (14d), and recipient (14e). In addition to recipient, it also encodes other functions that are typical of dative markers including direction (14f), and experiencer (14g). (wa)gard encodes companion (14h), and co-participant (14i). These two adpositions often occur with the particle=ay, thus form circumpositions (Mahmoudveysi et al. 2012: 55).

(14) a. wa ča ma-š-ī?

INS what IND-go.PRS-2SG

'With what (kind of transportation) do you go?'

[Mahmoudveysi et al. 2012: 52]

b. wa $k a=y a \quad m a-w$-in

INS house $=$ POST IND-COP-3PL

'They are at home'

[Mahmoudveysi et al. 2012: 52]

c. wa lafz-e šīīn wa merabānì mard kam

INS speech-EZ sweet INS kindness man less

$n i-m a-w(u) \quad \check{c} i \quad m e \bar{r} d-\bar{a} n$

NEG-IND-become.PST like man-PL

'Through sweet speech, with kindness, a man does not make less of his manhood'

[Mahmoudveysi et al. 2012: 111] 


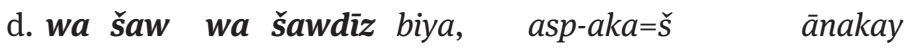
in night INS PN COP.PST horse-DEF=3SG.PC belong xasraw wa dizīwa PN in secret

'(It was) nighttime (and) she was with Šabdiz, her horse, which belongs to Xasraw. (She goes) in secret'] [Mahmoudveysi et al. 2012: 109]

e. min wa Ali nān ma-t-im

1SG INS PN bread IND-give.PRS-1SG

'I give Ali the bread.'

f. $p \bar{\imath} y \bar{a}=y(\check{c}) \quad m a-s ̌-u=w a \quad$ bān āsyāw-aka

man=ADD IND-go.PRS-3SG=INS up mill-DEF

'The man also goes up on the mill' [Mahmoudveysi et al. 2012: 58]

g. àyā min wa dit=im najūbūr-ìm

if $1 \mathrm{SG}$ INS heart=1SG.PC NEG.SBJV-COP must-1SG

bi-san- $m=i \check{S} \quad h \bar{a}$

SBJV-buy.PRS-1SG=3SG.PC NA

'If I do not like it, I have to buy it' [Mahmoudveysi et al. 2012: 56]

h. xozgā min āyamīzāya biyātā-yim $\bar{a} \quad$ tūta=y gard

I wish 1SG human.being be.PST.SBJV-1SG DEM dog=EZ COM

gala $=\boldsymbol{m}=\boldsymbol{a} \quad$ bi-kuštā

flock=1SG.PC=DEM SBJV-kill.PST.SBJV

'If I only were a human being, I would have killed that dog with the flock...'

[Mahmoudveysi et al. 2012: 42]

i. $h a(r)$ dük=šān tay qarār wa gard yak=ay ma-was-in

every both=3PL.PC contract COM one=POST IND-close.PRS-3PL

'Both of them make a contract together'

[Mahmoudveysi et al. 2012: 96]

It should be noted that in just two examples in the grammar the use of $w a$ for encoding companion was found, while for other occurrences of the companion wagard was used, which shows that the language is moving towards nonconnectivity in the instrumental-comitative domain. Also, wagard is a compound preposition formed by adding -gard to wa. Figure 12 below shows boundaries of wa and wagard in Gorani.

We might say that Gorani is in transition from languages like Persian which observe connectivity to languages like Sorani Kurdish which do not. In other words, Gorani is an intermediate stage between connectivity languages and nonconnectivity ones. 


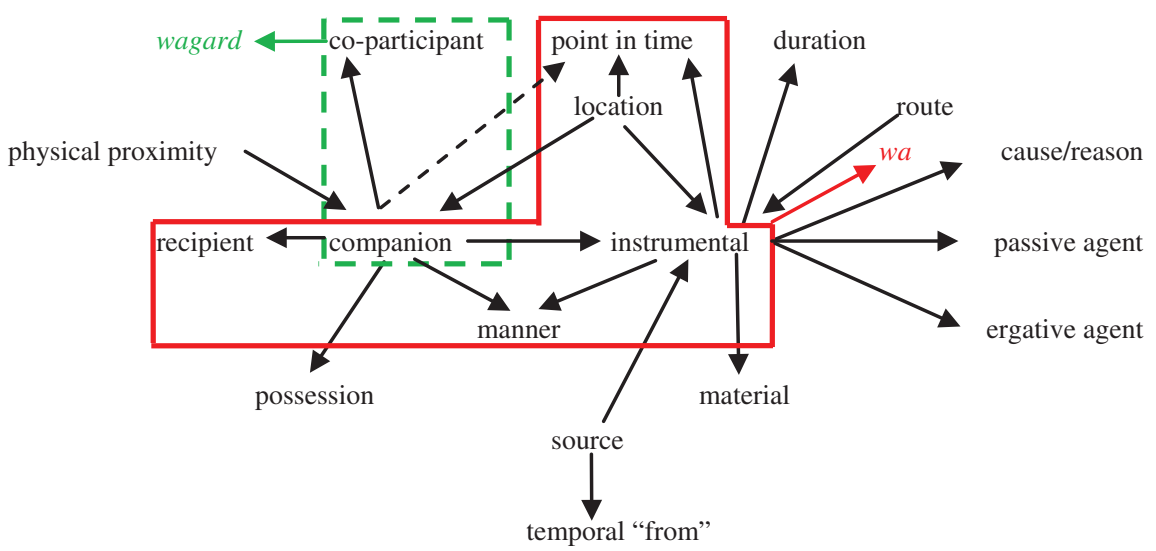

Figure 12: Boundaries of wa and wagard in Gorani.

\subsubsection{Hawrami}

Hawrami is a Gorani dialect and probably the most archaic and best preserved of the group (MacKenzie 1966: 4). In Hawrami, as we have seen before with some other languages, two prepositions encode instrumental-related functions: $b a$ (pana, pə as absolute preposition forms of $b a$ ) functions as instrument (15a), recipient (15b), point in time (15c), and manner (15d). It also marks direction (15e) which together with recipient are typical functions of dative markers. Čani is the other preposition encoding companion (15f) and co-participant (15g):

a. $d a s=e \check{s}$

$\check{S} l t$

wa ba fotewi nāyāb

hand=3SG.PC wash.PST and INS towel-EZ fine

asari- $e=\check{S}$

dry.PST-3PL=3SG.PC

'He washed his hands and dried them on a fine towel'

[MacKenzie 1966: 68]

b. $d \bar{a}=\check{s}$

ba hama-y u ad=Eš

give.PST=3SG.PC INS PN-OBL a mother=3SG.PC

'He gave it to Hama and his mother'

[MacKenzie 1966: 53]

c. ba zārola-I har ba pāy pāwīruā lu-ene rā-na

INS childhood-OBL ever INS foot-Ez bare go.PST-1SG road-LOC

'In (my) childhood I used to always walk about barefoot'

[MacKenzie 1966: 61] 
d. $\boldsymbol{b a}$ ayš-u-noš $i \quad$ diniā-y-a b-ar-me sar INS pleasure ADP world-EP-ADP SBJV-bring.PRS-1PL head 'Let us live out this life in pleasure'

[MacKenzie 1966: 62]

e. ja duari-aka di-ane panj šiš suār=em

from window-DEF look-1SG five six horsemen=1SG.PC

di-e, $\quad \check{r}$ ba egay ene

see.PST-3PL face INS here come.PST.3PL

'I looked through the window and saw five or six horsemen coming in this direction'

[MacKenzie 1966: 61]

f. $\operatorname{am}(\partial n) \quad \check{c}$ ani $=\boldsymbol{t} \quad m-a-w$

1SG $\quad \mathrm{COM}=2 \mathrm{SG} . \mathrm{PC}$ IPFV-come.PRS-1SG

'I will come with you'

g. piyay-wa $q($ a)se=t čani kar-e moallem-an

man-INDF talk=2SG.PC COM do-IPFV teacher-COP.3SG

'The man who was talking with you, is a teacher'

[Dabir-Moghaddam 2013: 799]

The map for Hawrami is given below:

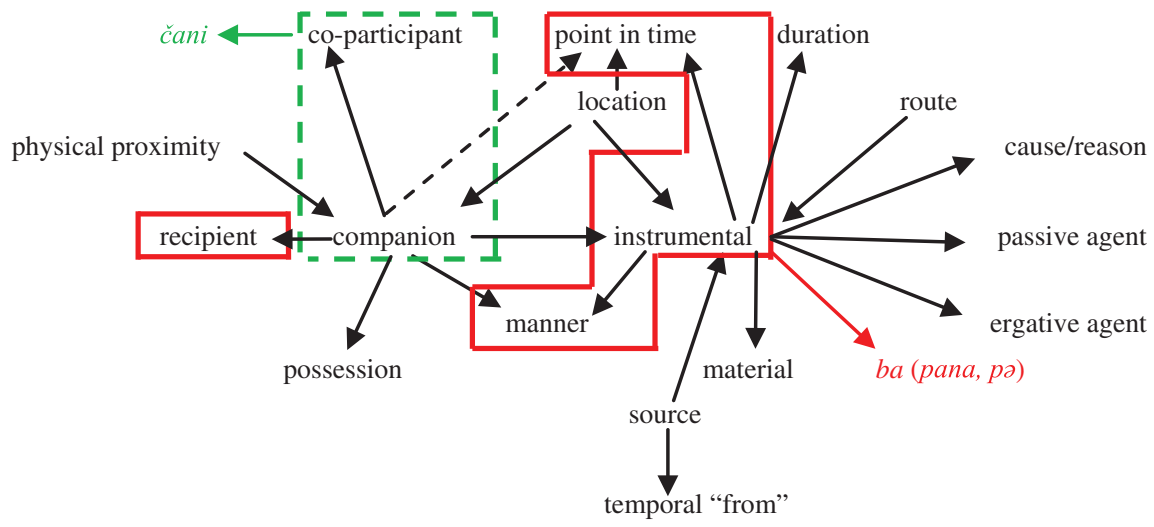

Figure 13: Boundaries of ba (pana, pə) and čani in Hawrami.

In Hawrami, like Sorani Kurdish, Kalhori Kurdish, and Gorani, connectivity is not observed, and one marker has both instrumental and dative functions.

\subsubsection{Tat}

Tat refers to a group of closely related Iranian languages spoken in Azerbaijan and Daghestan. They are classified as the south-western branch of Iranian 
languages. The dialect that we describe its polysemy pattern in the instrumental-comitative domain is Jewish Tat, or Juhuri, described in detail by Authier (2012). In Juhuri Tat, the instrumental marker is a circumposition preceded by both the locative $\mathrm{e}=$ at the left of the phrase, and the dative $=(r) e$ at the right of the phrase followed by $v o z$, thus forming e....(r)evoz/e...ovoz. It marks instrument (16a), companion (16b), co-participant (16c), cause (16d), duration (16e) and manner (16f):

a. kuk $\boldsymbol{e}=$ korde=revoz bur-ri $u=r e \quad q o z-\ddot{a}-q o z$. boy $\mathrm{LOC}=\mathrm{knife}=\mathrm{INS}$ cut-PST $3 \mathrm{SG}=\mathrm{DAT}$ nut-to-nut 'With a knife, the boy cut the nuts one by one'

[Authier 2012: 99]

b. qärevoş=iş $\quad \boldsymbol{e}=\boldsymbol{y} \boldsymbol{u}=\boldsymbol{r e v o z}=\boldsymbol{i}$ servant $=$ ADD $\quad$ LOC $=$ DIST $=$ INS $=$ COP.3SG

'The servant is also with her' [Authier 2012: 58]

c. $i \quad \boldsymbol{e}=\boldsymbol{y} \boldsymbol{u}=\boldsymbol{r e v o z}$ vepiçi-rebu=ho jovon-e pehlivon this LOC=DIST=INS wrestle-PPRF=NMLZ young-ATTR hero duxder bi-re=bebey! girl be-PTCP=EVID

'This young hero who had fought with him was actually a girl!'

[Authier 2012: 227]

d. $\boldsymbol{e}=\boldsymbol{i}=\boldsymbol{r e v o z} u$-ho heçi dulanmiş bi-rembir-üt. LOC=this=INS 3-PL so living be-IPFV.PST-3PL 'Thanks to this, they lived somehow.'

[Authier 2012: 115]

e. $u \quad \boldsymbol{e}=\boldsymbol{m e h}$-ho=revoz bi-rembu $\quad e=d i h$. 3SG LOC=month-PL=INS be-IPFV.PST LOC=village 'He was in the village for months.'

[Authier 2012: 110]

f. duxder-le e=tekeburi=revoz johob do. girl-DIMIN LOC=pride=INS answer give.PST 'The little girl replied proudly.'

[Authier 2012: 110]

The map for Juhuri Tat is given below.

In Tat, like most languages we have seen so far, connectivity is observed, and instrumental and companion functions are encoded in the same way.

The range of functions of instrumental marker demonstrates similarities as well as differences across Western Iranian languages. In the next section, we discuss this in detail and the consequences it has for semantic maps. 


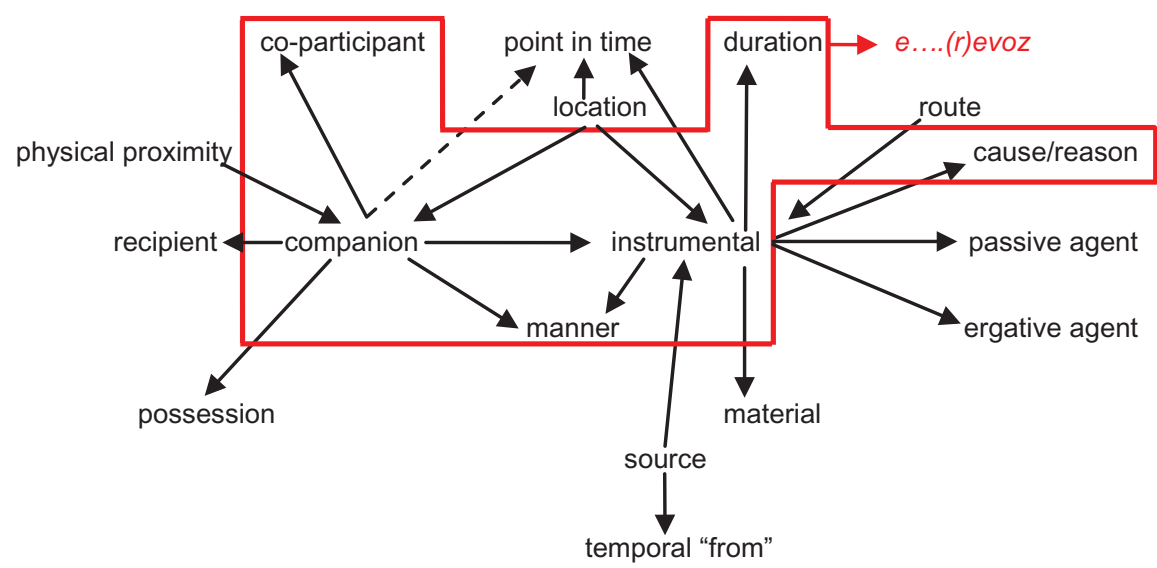

Figure 14: Boundaries of e......(r)evoz in Tat.

\section{Results and findings}

The data from new Western Iranian languages show that there exist two polysemy patterns for instrumental-comitative domain:

(1) Instrumental and companion, the core instrumental functions, are encoded with the same marker. This is the case with the majority of languages including New Persian and Bakhtiari (Figure 2), Gilaki (Figure 3), Mazandarani (Figure 4), Balochi and Koroshi (Figure 5), Taleshi (Figure 6), Tati (Figure 7), Kermanshahi Kurdish (Figure 11), and Tat (Figure 14); these languages observe connectivity, and instrumental and dative markers are different.

(2) Instrumental and companion are encoded differently. Kurmanji Kurdish (Figure 8), Sorani Kurdish (Figure 9), Kalhori Kurdish (Figure 10), Hawrami (Figure 13), and Gorani (Figure 12) follow this pattern. Apart from Kurmanji, other languages in group (2) do not observe connectivity; one marker encodes both instrumental and dative functions and a different marker encodes companion. It is not clear whether the marker encoding both dative and instrumental functions should be considered as an instrumental marker or a dative marker. We might say instead that one marker encodes both instrumental and dative related functions. The existence of non-connectivity in these languages poses exceptions to the connectivity hypothesis. According to Narrog and Ito (2007: 289), this happens at a point when the old morpheme has become fairly broad in its semantic rangetherefore opaque to the speakers of the language, and a newer morpheme 
comes in, expressing the semantic function in question more unambiguously. It seems plausible to hypothesize that for the non-connectivity languages in (2) the same scenario happens, that is, the general oblique marker, the one encoding both instrumental and dative related functions, becomes too broad in its semantic range and a new marker, the one encoding companion and co-participant, comes in and compensates for the opacity in the semantic range of the general oblique marker. This hypothesis is triggered by the fact that the companion marker in group (2) is a compound preposition (bu it's a circumposition in Kurmanji, comprising of postposition -re plus the instrumental marker bi), thus a recent one, while the general oblique marker is a simple preposition. In other words, we might say we deal with a grammaticalization cycle in which new markers compensate for the opacity in the range of functions the old markers encode. However, lack of diachronic data for non-connectivity languages can pose problems for this argumentation. Needless to say, this situation does not occur in languages of type (1) plus Kurmanji, simply because different markers realize polysemy in instrumental and dative domains, thus the semantic range of markers -instrumental in our case is not too broad for a new marker to come in compensating for opacity in the instrumental-comitative domain.

We refer to languages in (1) as connectivity type, and those in (2) as nonconnectivity type. But note that in spite of its labeling as a member of pattern (2), that is, different markers for instruments and comitatives, Kurmanji falls into the connectivity type. Between these two types, transitory states can be seen and languages like Gorani (Figure 12) seemingly represent this transition; the old morpheme is giving its place to a new marker with companion and co-participant functions. This hypothesis is triggered by the fact that only two uses of wa (the old morpheme) for companion function were attested in the whole grammar, while for all other occurrences of companion function the new morpheme wagard was attested. In other words, Gorani is in the process of shifting from connectivity type to non-connectivity type. Another explanation for non-connectivity in Gorani, besides semantic opacity proposed above, can be attributed to contact-induced matters, since the language is in heavy contact with Kalhori Kurdish (Figure 10), Hawrami (Figure 13), and to a lesser extent Sorani Kurdish (Figure 9), all of them belonging to the non-connectivity type. The effect of contact on the change of type in under-investigated languages can also be traced in the Kurdish variety spoken in Kermanshah (Figure 11). Here, the language has shifted from non-connectivity type to connectivity type, and it is 
presumably due to the presence of the heavy contact situation between Persian and Kurdish in Kermanshah.

The data clearly reveal that these two types are not stable and languages are shifting from one type to another mainly as a result of contact-induced matters. However, since Persian is the official language of Iran and the sole medium of education, the change from non-connectivity type to connectivity type is more likely to occur for those language varieties spoken in Iran.

There exist also areal polysemy patterns in the instrumental-comitative domain. Polysemy patterns are somehow unified in some areas; in Kurdishspeaking areas, for instance, in the west of Iran/north-east of Iraq, where also Hawrami and Gorani are spoken, there is a strong tendency towards non-connectivity. In languages around the Caspian Sea including Gilaki, Mazandarani, Taleshi, and Tati, the main polysemy pattern is the connectivity one. This is also true for Balochi and Koroshi. It is highly possible that that the main polysemy pattern for so-called south-western Iranian languages is also of the connectivity type; this is confirmed by the data from New Persian, Bakhtiari, Tat, and Delvari (see the data in Haig and Nemati 2013).

Among linguists, two different positions are held regarding the directionality of meaning change between instruments and companions (see Narrog 2010: 240 for an overview). Interestingly, the data from Western Iranian languages yield different developments for instrumental and companion markers in type (1) and type (2) languages. The instrumental marker in Persian gives us insights about the directionality of meaning change from companion to instrument; the companion marker $a b \bar{a} g$ in Middle Persian has extended its meaning to encode instrumental and other related functions in New Persian (Figure 2). For languages in type (2), at least for Kalhori and Gorani, the companion marker is formed by adding an element to the general oblique marker (Kalhori, "wagard" > "wa" + "gard") which encodes both instrumental and dative functions.

The question that remains unanswered is how to deal with the functionality of markers in type (2) languages on the map? Here, a marker has both instrumental related functions and dative ones. So, do we need to add some lines to the instrumental semantic map? Or to the dative map? It is true that the map proposed by Narrog is more developed than the one existing for dative functions (Haspelmath 2003). However, one cannot say for sure which path to take. Interestingly, there is a link between dative and instrumental functions on the map, "recipient", which is the prototypical dative function (Newman 1996: 82). It can be assumed that through "recipient" function, other functions in the dative semantic map be added to the instrumental map. Further cross-linguistic study is indeed required to have such changes on Narrog's map. 


\section{Summary}

The present paper aimed at showing polysemy patterns in the instrumental-comitative domain of a number of Western Iranian languages. The data showed that two polysemy patterns were attested; (1) instrumental and companion were coded alike. (2) They were coded differently. These two polysemy patterns are productive in Western Iranian languages, with the first one being more attested. The interesting point was the fact that languages are shifting/have shifted between these two types mainly as a result contact-induced matters. The presence of non-connectivity in type (2) languages can be attributed to factors such as contact, diachrony, and semantic opacity. How to deal with dative functions that are linked to instrumental related functions on the map requires further cross-linguistic study.

Acknowledgements: We express our gratitude to Heiko Narrog and the reviewers for their rich feedback on the first version of this paper. Any remaining shortcomings are our sole responsibility. This work has received funding from the European Union's Horizon 2020 research and innovation program under the Marie Skłodowska-Curie grant agreement No 665850.

\section{Abbreviations}

$\begin{array}{ll}\text { ACC } & \text { accusative } \\ \text { ADD } & \text { additive } \\ \text { ADP } & \text { adposition } \\ \text { ADVLZ } & \text { adverbilizer } \\ \text { ATTR } & \text { attributive } \\ \text { AUG } & \text { augment } \\ \text { AUX } & \text { auxiliary } \\ \text { CAUS } & \text { causative } \\ \text { CLF } & \text { classifier } \\ \text { COM } & \text { comitative } \\ \text { COMP } & \text { complementizer } \\ \text { COP } & \text { copula } \\ \text { DAT } & \text { dative } \\ \text { DEF } & \text { definite } \\ \text { DEM } & \text { demonstrative } \\ \text { DIMIN } & \text { diminutive } \\ \text { DIR } & \text { direct } \\ \text { DIST } & \text { distal } \\ \text { EP } & \text { epenthesis } \\ \text { EVID } & \text { evidentiality } \\ \text { EZ } & \text { ezafeh }\end{array}$




\begin{tabular}{|c|c|}
\hline $\mathrm{F}$ & feminine \\
\hline GEN & genitive \\
\hline IMP & imperative \\
\hline IND & indicative \\
\hline INDF & indefinite \\
\hline INF & infinitive \\
\hline INS & instrumental \\
\hline 10 & indirect object \\
\hline IPFV & imperfective \\
\hline LOC & locative \\
\hline M & masculine \\
\hline NA & not analyzed \\
\hline NEG & negative \\
\hline NMLZ & nominalizer \\
\hline OBJ & object \\
\hline OBL & oblique \\
\hline PASS & passive \\
\hline PC & personal clitic \\
\hline PL & plural \\
\hline PN & proper noun \\
\hline POST & postposition \\
\hline PPRF & pluperfect \\
\hline PROX & proximal deixis \\
\hline PRF & perfect \\
\hline PRS & present \\
\hline PST & past \\
\hline PTCP & participle \\
\hline PVB & preverb \\
\hline $\mathrm{RCH}$ & relative clause head marker \\
\hline RECP & reciprocal \\
\hline REL & relativizer \\
\hline REFL & reflexive \\
\hline SBJV & subjunctive \\
\hline SG & singular \\
\hline TOP & topic \\
\hline TR & transitive \\
\hline
\end{tabular}

\section{References}

Anderson, Lloyd B. 1982. The 'perfect' as a universal and as a language-particular category. In Paul J. Hopper (ed.), Tense-aspect: Between semantics \& pragmatics, 227-264. Amsterdam: Benjamins.

Anderson, Lloyd B. 1986. Evidentials, paths of change, and mental maps: Typologically regular asymmetries. In Wallace Chafe \& Johanna Nichols (eds.), Evidentiality: The linguistic encoding of epistemology, 273-312. Norwood: Ablex. 
Anonby, Erik \& Ashraf Asadi. 2014. Bakhtiari studies: Phonology, text, lexicon. Uppsala: Acta Universitatis Upsaliensis.

Authier, Gilles. 2012. Grammaire juhuri, ou judéo-tat, langue iranienne des Juifs du Caucase de l'est. Wiesbaden: Reichert.

Auwera, Johan van der. 2013. Semantic maps: For synchrony and diachrony. In Anna Giacalone Ramat, Caterina Mauri \& Piera Molinelli (eds.), Synchrony and diachrony: A dynamic interface, 153-176. Amsterdam: Benjamins.

Auwera, Johan van der \& Andrej Malchukov. 2005. A semantic map for depictive adjectivals. In Nikolaus P. Himmelmann \& Eva Schultze-Berndt (eds.), Secondary predication and adverbial modification, 393-421. Oxford: Oxford University Press.

Auwera, Johan van der \& Vladimir A. Plungian. 1998. Modality's semantic map. Linguistic Typology 2(1). 79-124.

Axenov, Serge. 2006. The Balochi language of Turkmenistan. A corpus-based grammatical description [Studia Iranica Upsaliensia 10]. Uppsala: Acta Universitatis Upsaliensis.

Bedir Khan, Emir \& Roger Lescot. 1970. Grammaire kurde (dialecte kurmandji). Paris: Adrien Maisonneuve.

Croft, William. 2001. Radical construction grammar. Syntactic theory in typological perspective. Oxford: Oxford University Press.

Croft, William. 2003. Typology and universals. Cambridge: Cambridge University Press.

Croft, William \& Keith T. Poole. 2008. Inferring universals from grammatical variation:

Multidimensional scaling for typological analysis. Theoretical Linguistics 34(1). 1-37.

Cysouw, Michael. 2007. Building semantic maps: The case of person marking. In Matti Miestamo \& Bernhard Wälchli (eds.), New challenges in typology, 225-248. Berlin: Mouton.

Cysouw, Michael, Martin Haspelmath \& Andrej Malchukov. 2010. Introduction to special issue "Semantic maps: Methods and applications". Linguistic Discovery 8(1). 1-3.

Dabir-Moghaddam, Mohammad. 2013. Typology of Iranian languages. 2 vols. Tehran: Samt.

Haig, Geoffrey \& Fatemeh Nemati 2013. Clitics at the syntax-pragmatics inference: The case of Delvāri pronominal enclitics. Conference paper held at the ICIL 5, Bamberg.

Haspelmath, Martin. 1997a. Indefinite pronouns. Oxford: Oxford University Press.

Haspelmath, Martin. 1997b. From space to time: Temporal adverbials in the world's languages. Munich/Newcastle: Lincom Europa.

Haspelmath, Martin. 2003. The geometry of grammatical meaning: Semantic maps and crosslinguistic comparison. In Michael Tomasello (ed.), The new psychology of language. Vol. 2, 211-242. Mahwah, NJ: Erlbaum.

Jahani, Karina \& Agnes Korn. 2009. Balochi. In Gernot Windfuhr (ed.), The Iranian languages, 634-692. London/New York: Routledge.

Janda, Laura A. 2007. Aspectual clusters of Russian verbs. Studies in Language 31. 607-648.

Kemmer, Suzanne. 1993. The middle voice. Amsterdam/Philadelphia: John Benjamins.

Lehmann, Christian \& Yong-Min Shin. 2005. The functional domain of concomitance. A typological study of instrumental and comitative relations. In Christian Lehmann (ed.). Typological studies in participation, 9-104. Berlin: Akademie Verlag.

Levinson, Stephen C., Sergio Meira \& the Language and Cognition Group. 2003. 'Natural concepts' in the spatial topological domain - adpositional meanings in crosslinguistic perspective: An exercise in semantic typology. Language 79(3). 485-516.

Luraghi, Silvia. 2001. Syncretism and the classification of semantic roles. Language Typology and Universals/STUF 54(1). 35-51. 
MacKenzie, David N. 1966. The dialect of Awroman (Hawrāmānī luhōn). Kobenhaven:

Det Kongelige Danske Videnskabernes Selskab.

Mahmoudveysi, Parvin, Denise Baily, Ludwig Paul \& Geoffrey Haig. 2012. The Gorani language of Gawraju, a village of West Iran. Texts, grammar, and lexicon. Wiesbaden: Reichert.

Malchukov, Andrej L. 2004. Towards a semantic typology of adversative and contrast marking. Journal of Semantics 21(2). 177-198.

McCarus, Ernest N. 2009. Kurdish. In Gernot Windfuhr (ed.), The Iranian languages, 587-633. London/New York: Routledge.

Najafi, A. 1999. Colloquial Persian dictionary. Tehran: Niloofar.

Narrog, Heiko. 2009. Varieties of instrumental. In Andrej Malchukov \& Andrew Spencer (eds.), The Oxford handbook of case. Oxford: Oxford University Press.

Narrog, Heiko. 2010. A diachronic dimension in maps of case functions. Linguistic Discovery 8(1). 233-254.

Narrog, Heiko \& Shinya Ito. 2007. Reconstructing semantic maps: The comitative-instrumental area. Language Typology and Universals/STUF 60(4). 273-292.

Newman, John. 1996. Give: A cognitive linguistic study. Berlin/New York: Mouton de Gruyter.

Nourzaei, Mariam, Carina Jahani, Erik Anonby \& Abbas Ali Ahangar. 2015. Koroshi. A corpusbased grammatical description. Uppsala: Acta Universitatis Upsaliensis.

Paul, Daniel. 2011. A comparative dialectal description of Iranian Taleshi. Ph.D. dissertation, University of Manchester.

Rastorgueva, V. S., A. A. Kerimova, A. K. Mamedzade, L. A. Pireiko \& D. I. Edel'man. 2012. The Gilaki language. Uppsala: Acta Universitatis Upsaliensis.

Rice, Sally \& Kaori Kabata. 2007. Crosslinguistic grammaticalization patterns of Allative. Linguistic Typology 11(3). 451-514.

Samvelian, Pollet. 2007. A (phrasal) affix analysis of Persian Ezafe. Journal of Linguistics 43(3). 605-645.

Stassen, Leon. 1997. Intransitive predication. Oxford: Oxford University Press.

Stilo, Donald. 2016. Mazanderani, entry for Encyclopedia Iranica (draft version).

Stolz, Thomas, Cornelia Stroh \& Aina Urdze. 2013. Comitatives and instrumentals. In Matthew S. Dryer \& Martin Haspelmath (eds.), The World Atlas of Language Structures online. Leipzig: Max Planck Institute for Evolutionary Anthropology. http://wals.info/chapter/52 (Accessed 20 July 2015)

Thackston, Wheeler M. 2006a. Kurmanji Kurdish. A reference grammar with selected readings. http://www.fas.harvard.edu/ iranian/Kurmanji/

Thackston, Wheeler M. 2006b. Sorani Kurdish. A reference grammar with selected readings. http://www.fas.harvard.edu/ iranian/Sorani/

Windfuhr, Gernot. 2009. The Iranian languages. London/New York: Routledge.

Yamaguchi, Kazuyuki.2004. A typological, historical, and functional study of adpositions in the languages of the world. PhD thesis, University of New Mexico.

Yar-Shater, Ehsan. 1969. A grammar of Southern Tati dialects. The Hague/Paris: Mouton. 